(C) 1983 ISIJ

\title{
鋼材の表面物性とその評価技術 一（II）分析技術一
}

\section{Characterization and Control of Steel Surfaces}

\author{
(II) Analyses —
}

\section{Yoshihiro Hisamatsu}

本報告は「鋼材の表面物性に関する基礎研究部会」の 中間報告のらち，第 2 部として表面分析関係をまとめた ものである.

鋼材の表面物性を研究するためには，当然，基礎とし て表面分析法の確立が必要であるが，一方，表面分析の 結果を正しく解釈するためには，その分析法自身の問題 点と同時に，鋼材表面をどのように理解しているか，す なわち金属表面に対する考方がどのように確立してい るかといらことが問題になる。そして金属表面に対する 理解を確立するためにはその前提としてまた表面分析法 の確立が必要であり，これらは颃互いに自家撞着の関係 にある.ここにバルクの組成分析と異なつた, 表面分析 の大きな特徽と困難さがあり，また同時に表面分析の面 白さもあるのであろら．このよらな表面分析のむずかし さと面白さが抒からいただければ幸いである。

(幹事 新居和嘉)

\section{6. 鉄を中心とした物質の表面分析用標 準試料群の調製とその応用性}

東北大学金属材料研究所広川吉之助

\section{1 はじめに}

表面分析を始め，機器による“正確な定量分析”には 標準試料群が不可欠である. 分光化学的手法による分析 の場合には基準スペクトルパターンなどの重㸚わせに より, 元素の存在状態を, スペクトル強度によりその量 を半定量的に推定できる場合が多い，現在表面分析に応 用されているX線光電子分光法 (X-ray Photoelectron Spectroscopy : XPS) とオージェ電子分光法 (Auger
Electron Spectroscopy：AES) ではその情報を得る 深 さが数 $\mathrm{nm}$ 以下と浅いため, その表面の化学状態と化学 組成を，ともに測定試料に近くきちんと規制した標準試 料群を作成することは困難か，不可能に近い，そのため 標準試料群を使用しない表面分析法の確立を第一の目的 とし, さらに正確度の向上を目指して, ある特定の試料 群については定量のための相対感度係数（定量補正係数） を得るため, 標準試料群の調製が可能な試料の種類の選 定と, その测定表面の作り方，そして测定方法の評価を 検討することを第二の目的とした.

\section{$6.2 X P S$ による定量分析}

標準試料群の有無にかかわらず XPS での定量分析は （1）式を基準としている。もちろん標準試料群を使用し ない分析の場合にはこの式が出発点となる.

ある平板試料の表面下 $x$ の微小部 $d x$ よりの電子線 強度 $d e_{\mathrm{x}}$ は

$$
\begin{array}{r}
d e_{\mathrm{X}}=k I_{\mathrm{X}} \cdot \sigma_{\mathrm{i} 1} \cdot f\left(\beta_{\mathrm{i} 1}\right) \cdot \delta_{\mathrm{i} 1} \cdot R \cdot n_{\mathrm{i}} \cdot \exp \\
\quad\left(\frac{-x}{\lambda_{\mathrm{i} 1} \cdot \cos \alpha}\right) d x \ldots \ldots \ldots \ldots \ldots \ldots \ldots \ldots \ldots \ldots \ldots \ldots \ldots \ldots \ldots \ldots \ldots
\end{array}
$$

ただしX線の透過深さは電子の脱出深さより数オーダー 大きいとする． $I_{\mathrm{x}}$ はX線束, $\sigma_{\mathrm{i} 1}$ は $\mathrm{i}$ 元素の $l$ 殼からの 電子の光イオン化断面積, $f\left(\beta_{i 1}\right)$ は $\mathrm{i}$ 元素 $l$ 殼からの電 子の非対称因子 $\beta_{\mathrm{i} 1}$ の関数, $\delta_{\mathrm{i} 1}$ は検出系を含む分光器 関数, $R$ は表面粗さ係数, $n_{\mathrm{i}}$ は単位体積中 $\mathrm{i}$ 元素の原 子数, $\lambda_{\mathrm{i} 1}$ は $\mathrm{i}$ 元素 $l$ 殸からの電子の脱出深さ, $\alpha$ は電 子の取り出し角である. この式を 0 からのに積分した り，適当な仮定（例えば表面薄層下のバルク組成は均一 であるなど）を入れて計算を実施したりする。

昭和 58 年 5 月 13 日受付 (Received May 13，1983)

* 本会特定基礎研究会鋼材の表面物性に関する基礎研究部会部会長 日新製鋼(株) 常勤顧問 東京大学名誉教 授 工博 (Nisshin Steel Co., Ltd., 3-4-1 Marunouchi Chiyoda-ku 100)

鋼祆の表面物性とその評価技術 一-(I)物性・応用技術一 は，「鉄と鋼」第 69 年第 11 号（1983 年 9 月

号）に掲載. 主要目次は以下のとおり.

1. 鉄鋼材料の表面偏析および表面析出の制御に関する研究

2. エリプソメトリーおよび変調可視紫外反射分光法によるステンレス鋼表面皮膜の解析

3. 電子ェネルギー損失分光 (EELS) による表面物性の研究

4. 鋼材表面層の組織之結合状態の解析

5. 鉄鋼へのイオン注入（I）一注入イオン分布へのスパッタリングの影響一 
標準試料群を使用しない分析法に対しては各パラメータ の值が必要である。 まず光イオン化断面積 $\sigma$ は SCOFIELD の值1を用いる。ただし，SCOFIELD の值は自由原子 モデルに基づく Hatree-Fock 法による計算で求められ ているため化合状態で大きく変化する最外殼電子2) に対 しては用いることがでさない，そのため本法で使用する スペクトル線も内殼レベルの線である. 非対称因子 $\beta$ は ReILman らの值光を, 電子の平均自由工程 $\lambda$ は PENN ${ }^{4)}$ または Seah-Dench ${ }^{5)}$ の式か， $\lambda \propto E_{\mathrm{k}}^{0.76)}$ の実験式が有効 である.しかしそれらの相対值を用いる場合には，いず れの方式で求めても大きな差は認められないて，検出系 を含めての装置関数 $\delta$ は各装置について必ず実験をして 求めて打く必要がある ${ }^{8)}$ 10). とくに相対感度係数を求 めて定量を行ら場合にはその係数の中に含まれる感度係 数 $\delta$ の值が各装置により異なるので, 他の装置で求めた 相対感度係数を，そのまま比較したり，使用してはなら ない11). X線励起-オージェ電子スペクトルを定量に使 用する場合はオージェ強度係数を各元素の状態に対して 求めて使用すると便利である14)。これらのパラメータを 含んだ補正係数，すなわち相対感度係数はXPS のよう に内殼レベルの電子を使用する場合には真空中で安定な 化学量論的化合物群12)について求めて使用することがで きる。

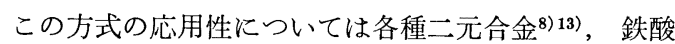
化物 ${ }^{14)}$, 鉄中の窒素や硫黄などについても確かめられ た15)。また前に述べた各種パラメータのらち装置関数 $S$ を除いたものを原子番号の関数として求め, これらの関 数を用いる定量計算のプログラムも開発された16).

\subsection{AES による定量分析}

AES の鉄鋼分野に対する応用はXPS よりむしろ古 い. 定量は標準試料群を使用し, 検量線を作製して行わ れる場合が多い。しかしこの場合には任意の試料につい て広い濃度範囲の定量が実施しがたい。また補正係数法 ではその補正係数を求める標準試料の種類と求め方にま だ問題が残されている.XPS のように実験的，物理的 に得られたパラメータを使用する方法を確立するには才 ージェ遷移確率などが満足に求められていない元素が多 い.一方 AES で測定され応用されるスペクトル線では 最外款電子の関与するスペクトル線（例えば $\mathrm{Fe} \mathrm{L}_{3} \mathrm{M}_{4,5}$ $\mathrm{M}_{4,5}, \mathrm{Cr} \mathrm{L}_{3} \mathrm{M}_{4,5} \mathrm{M}_{4.5}$ など）を使用する場合が多い，そ のため合金などを高真空中で破断した面や，研磨した面 のように化合物層を形成していない表面については相対 感度係数を用いる方法でも比較的よい精度, 正確度で定 量が可能であるが，空気中に放置された金属表面のよう に酸化物など化合物を形成している表面層に対しては, 化学形態によるプロファイルの変化, それにともなら相 対感度係数の変化などは無視できない，そこで測定試料 と同じ成分を含み, かつ同一の AES プロファイルを示
す標準物質または標準試料を調製して測定試料と同一条 件で測定し, 相対感度係数に相当する補正項部を消去す る方法により AES の定量化を試みている ${ }^{13)}$ 。この場合 には (1) 式の $d e_{\mathrm{x}}$ に相当する電子線強度 $d e_{\mathrm{A}}$ は (2) 式の ように与えられ, 無限厚さの試料を想定したり, 試料の 表面粗さの項を消去するため同一試料内の 2 元素からの 強度比を採用したりして補正項の処理が行われている.

$$
\begin{aligned}
& d e_{\mathrm{A}}=k I_{\mathrm{A}} \cdot Q_{\mathrm{iA}} \cdot A_{\mathrm{iA}} \cdot B_{\mathrm{iA}} \cdot S_{\mathrm{iA}} \cdot R \cdot n_{\mathrm{i}} \cdot \\
& \quad \exp \left(\frac{-x}{\lambda_{\mathrm{iA}} \cdot \cos \alpha}\right) \cdot \exp \left(\frac{-x}{\lambda_{\mathrm{A}} \cos \theta}\right) d x
\end{aligned}
$$

ただし， $Q_{\mathrm{iA}}$ は電子イオン化断面積， $A_{\mathrm{iA}}$ はオージェ 遷移確率， $B_{\mathrm{iA}}$ は背面散乱電子ならびにイオン化にとも ならエネルギー損失などに関する係数, $I_{\mathrm{A}}$ は照射電子線 束， $\lambda_{\mathrm{AA}}, \lambda_{\mathrm{A}}$ はオージェ電子ならびに照射電子の透過長 さを示す. この方法を $\mathrm{Fe}-\mathrm{P}$ 合金の粒界破断面のりんに 適用し, AES とXPS の結果からりんがりん化物形の 結合状態であることから $\mathrm{Fe}_{3} \mathrm{P}$ としてその平均厚さの測 定などが試みられている. XPS と AES の両方法によ る結果は納得のゆく程度の差で満足すべきものが得られ ている13)17)。

\section{4 標準試料群の調製とその評価}

定量分析法の正確度をさらに向上させるためには, 標 準試料群を用意して, その標準スペクトラムや相対感度 係数などを求めて拉くことが望ましい．XPS の場合に は高真空中で安定な化学量論的化合物をそのまま使用で きる場合がある. しかし合金の場合は標準試料群の表面 として(1)試料のバルク平均組成と同じ組成の表面を得る こと, (2)測定表面層の化学状態と同じ化学状態の表面を 得ることが必要である. また(3)現在のところ(1)(2)の条件 は表面面積 $50 \mathrm{~nm}$ 直径, 深さ $5 \mathrm{~nm}$ 以下程度の均一度 であればよいが，将来はこれらの均一度も規制する必要 がある. 現在これらの条件を満たす測定表面を得ること のできる標準試料群として鉄鋼を中心とした試料を考え ると確実性のある表面作製方法として，（i 高真空中で 粒内破断を行うこと，(ii）高真空中で低温研磨または高 速切断を行うこと, (iii) ある特定の試料群の場合には特 定条件下でのガス吸着や電解などによる表面処理などが 考えられる.（ii)の方法は装置的な問題がかかわりあつ ているが，（i ）の方法は試料の本質に関係する部分が多 い. そこで筆者らは, 鉄基合金はどのような成分でどの 程度の組成範囲（組織なども考慮して）の合金に対し， (i)の方法が可能であり, 大まかであつてもある規則が あるか, また得られた表面から理想的な検量線が得られ るか, などを検討し，ぞのよらな試料調製や定量法が鉄 鋼の表面物性の諸検討に有効に応用できるかを検討して いる.としてそれとともに鉄鋼の表面，界面に存在する 物質の標準スペクトルパターンを, AES, XPS ともに 集めようとしている。 


\section{交献}

1) J. H. Scofield: J. Electron Spectrosc. Relat. Phenom., 8 (1976), p. 129

2) M. Oku: J. Solid State Chem., 23(1978), p. 177

$3) R . F$. Reilman, $A$. Msezane, and $S . T$. Manson: J. Electron Spectrosc. Relat. Phenom., 8 (1976), p. 389

4) D. P. Penn: J. Electron Spectrosc. Relat. Phenom., 9 (1976), p. 29

5 ) M. P. SeAH and D.A. Dench: Surf. Interface Anal., 1 (1979), p. 1

6 ) $K$. Hirokawa and $M$. Oku: Z. anal. Chem., 285 (1977), p. 192

7 ) $K$. Hirokawa and $Y$. Danzaki: Surf. Interface Anal., 2 (1980), p. 240

$K$. Hirokawa, $F$. Honda, and $M$. OKu: Z. anal. Chem., 286 (1977), p. 41

8 ) $K$. Hirokawa, $T$. Sato, and $M$. OKu: Z. anal. Chem., 297 (1979), p. 393

9 ) $M$. Vulli and $K$. SArbe: J. Phys. E., 16 (1977), p. 158

10) A. E. Hughes and $C$. C. Phyllips: Surf. Interface Anal., 4 (1982), p. 220

11) 広川吉之助, 奥 正興: 分析化学, 32(1983), T53 C. D. Wagner, L. E. Davis, M. V. Zeller, J. $A$. TAYlor, $R$. $H$. RAYMOND, and $H$. Gale: Surf. Interface Anal., 3 (1981), p. 211

12) $K$. Hirokawa and $Y$. Danzaki: Surf. Interface Anal., 4 (1982), p. 63

13) $K$. Hirokawa, $S$. Suzuki, $K$. Abiko, $H$. Kimura, and M. OKu: J. Electron Spectrosc. Relat. Phenom., 24 (1981), p. 243

14) М. Окu and K. Hirokawa: J. Appl. Phys., 50 (1979), p. 6303

$K$. Hirokawa and $M$. Oku: Talanta, 26 (1979), p. 855

15) $F$. Honda and $K$. Hirokawa: J. Electron Spectrosc. Relat. Phenom., 13 (1977), p. 313 広川吉之助, 奥 正興, 本多交洋: 分析化学, 26 (1977), T 7

$F$. Honda and $K$. Hirokawa: Talanta, 25 (1978), p. 383

16) $M . F$. Ebel, $H$. Ebel, and $K$. Hirokawa: Spectrochim Acta, 37B (1982), p. 461

17) $M$. Oku, $S$. Suzuki, $K$. Авiko, $H$. Kimura, and $K$. Hirokawa: J. Electron Spectrosc. Relat. Phenom., 23 (1981), p. 147

\section{7. 鉄鋼表面分析のための $\mathbf{X}$ 線光電子分 光法}

\author{
東北大学金属材料研究所 \\ 橋本功二 浅見勝彦
}

$\mathrm{X}$ 線光電子分光法は, $\mathrm{X}$ 線照射の結果, 光電効果によ つて放射される電子の運動エネルギーを測定するもので ある. その第 1 の特徽は放射された電子の固体内に打け る平均自由行程が数 $\mathrm{nm}$ であるため, 厚さ数 $\mathrm{nm}$ の表 面層から放射された光電子のみが分光され，薄い表面層
に関する知見を与えてくれることである. 第 2 の特 徵 は, 対象となる元素がイオン化すると, 測定される光電 子の運動エネルギーのピーク位置が比較的大きく移動す ることである．このことは，不働態皮膜が生じているス テンレス鋼では, 皮膜中の $\mathrm{Cr}^{3}+$ イオンと下地鋼中の金 属クロム $\left(\mathrm{Cr}^{\mathrm{m}}\right)$ とを非破壊で区別して分析することを 可能にし，また， $\mathrm{Mo}^{4+}, \mathrm{Mo}^{5+}, \mathrm{Mo}^{6+}$ のように，異な る価数のイオンがあれば, これらの区別をも可能にして くれる，第 3 の特徵は，水素を除くすべての元素につい て，比較的高い検出感度で，スペクトルが得られること である。

以下，筆者らが AEI-ES 200 X線光電子分光装置を 用いて実際に行つている分析方法を記す. 光電子の励起 源には，主として $\mathrm{MgK} \alpha_{1.2}$ 線 $1253.62 \mathrm{eV}$ を用いてい る。最初に広いエネルギー範囲にわたり，スペクトルを 測定し, 試料表面から検出される元素についての目安を らる. 次いで各元素について狭いェネルギー範囲にわた る詳細なスペクトルを測定する，例えば塩酸で処理した 316 ステンレス鋼であれば, Fe $2 \mathrm{p}_{3 / 2}, \mathrm{Cr} 2 \mathrm{p}_{3 / 2}, \mathrm{Ni} 2 \mathrm{p}_{3 / 2}$, Mo 3d, Cl 2p，Ols，G1s スペクトルは，少なくとも測 定しなければならない，それぞれの光電子の結合エネル ギーから定性分析が行える。

結合エネルギーの較正には，試料表面污染層に由来す る C1s スペクトルのピーク位置がしばしば用いられる が，炭素の種類によつて Cls スペクトルのピーク位置 が変動すること拈よび見掛けの仕事関数が運動エネルギ 一によつて異なることから，筆者らは $\mathrm{Au} 4 \mathrm{f}_{7 / 2},(84.07$ $\mathrm{eV}), \quad \mathrm{Au} 4 \mathrm{f}_{5 / 2}(87.74 \mathrm{eV}), \mathrm{Cu} 2 \mathrm{p}_{3 / 2}(932.53 \mathrm{eV}), \mathrm{CuLIII}$ MVMV オージェ電子（運動エネルギー918.65 eV）の 各スペクトルを別に測定し較正直線を作つている1)2)。

この場合, 見掛けの仕事関数は, 装置の状態によつて微 妙に変化するので，一連の測定を行う際には新しい較正 直線を作製して用いている。

金属元素のスペクトルからは，表面皮膜中のイオンの スペクトルと下地金属中の金属状態に対応するスペクト ルを分離し，それぞれの積分強度を求める．また $01 \mathrm{~s}$ スペクトルについては2)，低結合ェネルギー側にピーク を与える $\mathrm{O}^{2-}$ に対応する $\mathrm{OM}$ スペクトルと皮膜中の $\mathrm{OH}^{-}$や $\mathrm{H}_{2} \mathrm{O}$ の $\mathrm{O}$ に由来して高結合エネルギー側にピー クを生ずる $\mathrm{OH}$ スペクトルに分離して積分強度を求め る. スペクトルの分離は次のように行ら，厚さ数 $\mathrm{nm}$ の 表面皮膜を構成しているイオンのスペクトルのピーク位 置や形は，同じイオンからなるバルクの標準物質とは異 なるため，標準スペクトルは表面皮膜から求めることが 望ましい，そこで，純粋の金属状態のスペクトルを測定 する他，表面皮膜中の特定のイオンについて，これまで 測定した多数のスペクトルを標準物質のスペクトルとあ

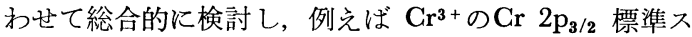
ペクトルを得，さらにスペクトルの裾の形を表す関数形 
や半価幅を求めて拈く，この標準スペクトルを用い，例 えば $\mathrm{Cr}^{\mathrm{m}}$ と $\mathrm{Cr}^{3}+$ について゚ークエネルギー差と強度比 を想定して合成スペクトルを作り，実測スペクトルと一 致するものを見出し，これから重畳している $\mathrm{Cr}^{\mathrm{m}}, \mathrm{Cr}^{3+}$ それぞれのスペクトルの積分強度を求める33.

求めるべきは, 表面に存在する各元素の状態と共にそ れらの濃度，および表面皮膜の厚さである．今，試料表 面が均一な厚さ $l$ 炭化水素污染層で覆われ, その下に 厚さ $t$ の表面皮膜があり，その下にはX線光電子の脱出 深さに比べて無限大の厚さをもつ下地合金層があり，表 面皮膜拉よび皮膜直下の合金中ではすべての元素が均一 に分布していると仮定すると，例光ば皮膜中の $\mathrm{Cr}^{3+}$ お よび下地合金中の $\mathrm{Cr}$ に対する Cr $2 \mathrm{p}_{3 / 2}$ スペクトルの 積分強度 $I_{\mathrm{Cr}}^{\mathrm{ox}} ， I_{\mathrm{Cr}}^{\mathrm{m}}$ はそれぞれ

$$
\begin{aligned}
& I_{\mathrm{C} r}^{o x}=g_{\mathrm{Cr}} \cdot \sigma_{\mathrm{C} r}^{o x} \cdot \Lambda_{\mathrm{Cr} r}\left(c_{\mathrm{C} r}^{o x} \cdot \rho^{0 \mathrm{x}} / A_{\mathrm{Cr} r}\right) \\
& \text { - }\left\{1-\exp \left(-t / \Lambda_{\mathrm{Cr}}\right)\right\} \exp \left(-l / \Lambda_{\mathrm{Cr}}\right) \\
& I_{\mathrm{C} r}^{\mathrm{m}}=g_{\mathrm{C}_{r}} \cdot \sigma_{\mathrm{C} r}^{\mathrm{m}} \Lambda_{\mathrm{Cr}}\left(c_{\mathrm{C} r}^{\mathrm{m}} \cdot \rho^{\mathrm{m}} / A_{\mathrm{Cr}}\right) \\
& \cdot \exp \left\{-(t+l) / \Lambda_{\mathrm{Cr}}\right\}
\end{aligned}
$$

とあらわされる。ここで上付き記号 ox と $\mathrm{m}$ は表面皮 膜和よび下地合金に対応する. $g$ は計数効率とか照射 $\mathrm{X}$ 線の強度などを含む幾何学的因子， $\sigma$ は光イオン化断面 積, $\Lambda$ は有効脱出深さ ((光電子取り出し角の正弦 $) \times$ (脱出深さ)).$c$ は皮膜中あるいは下地合金中の問 題 と する元素の重量分率, $\rho$ は密度, $A$ は原子量である. 炭 化水素污染層中の炭素から得られる C1s スペクトルの 積分強度についても同様の式が得られる.

$$
I_{\mathrm{C}}^{\mathrm{con}}=g_{\mathrm{C}} \sigma_{\mathrm{C}} \Lambda_{\mathrm{C}}\left(c_{\mathrm{C}}^{\mathrm{con}} \cdot \rho^{\mathrm{con}} / A_{\mathrm{C}}\right)\left\{1-\exp \left(-l / \Lambda_{\mathrm{C}}\right)\right\}
$$

ここで上付き記号 con は污染物質層を意味する. 光イ オン化断面積は, 実験的には元素間の此として求められ るので，通常の金属材料の表面には必ず存在する酸素に よる $\mathrm{O} 1 \mathrm{~s}$ スペクトルの積分強度に対する比としても (1)〜 (3)の積分強度をあらわすと

$$
\begin{aligned}
& \frac{I_{\mathrm{Cr}}^{\mathrm{ox}}}{I_{\mathrm{O}}^{o x}}=\frac{g_{\mathrm{Cr}} \sigma_{\mathrm{Cr}}^{o x} \Lambda_{\mathrm{Cr}} A_{\mathrm{O}}}{g_{0} \sigma_{0} \Lambda_{0} A_{\mathrm{C} \mathrm{r}}} \frac{c_{\mathrm{Cr}}^{o x}}{c_{\mathrm{O}}^{o x}} \\
& \text { - } \frac{1-\exp \left(-t / \Lambda_{\mathrm{Cr}}\right)}{1-\exp \left(-t / \Lambda_{\mathrm{o}}\right)} \cdot \exp \left(\frac{l}{\Lambda_{\mathrm{o}}}-\frac{l}{\Lambda_{\mathrm{Cr}}}\right) \\
& \frac{I_{\mathrm{Cr}}^{\mathrm{m}}}{I_{\mathrm{O}}^{\mathrm{ox}}}=\frac{g_{\mathrm{Cr}} \sigma_{\mathrm{Cr}}^{\mathrm{m}} \Lambda_{\mathrm{Cr}} A_{\mathrm{O}}}{g_{0} \sigma_{\mathrm{o}} \Lambda_{0} A_{\mathrm{C} \mathrm{r}}} \cdot \frac{c_{\mathrm{Cr}}^{\mathrm{m}}}{c_{\mathrm{O}}^{0 \mathrm{x}}} \cdot \frac{\rho^{\mathrm{m}}}{\rho^{0 \mathrm{x}}} \\
& \cdot \frac{\exp \left(-t / \Lambda_{\mathrm{Cr}}\right)}{1-\exp \left(-t / \Lambda_{\mathrm{O}}\right)} \cdot \exp \left(\frac{l}{\Lambda_{\mathrm{O}}}-\frac{l}{\Lambda_{\mathrm{Cr}}}\right) \\
& \frac{I_{\mathrm{C}}^{\mathrm{con}}}{I_{\mathrm{O}}^{\mathrm{ox}}}=\frac{g_{\mathrm{C}} \sigma_{\mathrm{C}} A_{\mathrm{C}} A_{\mathrm{o}}}{g_{\mathrm{o}} \sigma_{\mathrm{o}} \Lambda_{\mathrm{o}} A_{\mathrm{C}}} \cdot \frac{c_{\mathrm{C}}^{\mathrm{con}}}{c_{\mathrm{O}}^{\mathrm{ox}}} \cdot \frac{\rho^{\mathrm{con}}}{\rho^{\text {ox }}} \\
& \cdot \frac{1}{1-\exp \left(-t / \Lambda_{0}\right)} \cdot \frac{1-\exp \left(-l / \Lambda_{\mathrm{C}}\right)}{\exp \left(-l / \Lambda_{0}\right)}
\end{aligned}
$$

がえられる. 表面皮膜を構成するすべての元素 $\mathrm{i}$ および

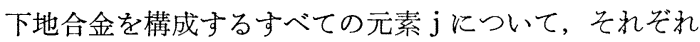
式 (4)および (5) と同様な式を作ることができる. 屯 た表面皮膜を構成するすべての元素の重量分率の 総 和 $\sum_{i} c_{i}^{0 x}$ および下地合金を構成する全元素の重量分率の総 和 $\sum_{\mathrm{j}} c_{\mathrm{j}}^{\mathrm{m}}$ はそれぞれ1である $\left(\sum_{1} c_{\mathrm{i}}^{\mathrm{n}}=1, \sum_{\mathrm{j}} c^{\mathrm{m}}=1\right)$ から

$$
\begin{aligned}
& \sum_{\mathrm{j}} I_{\mathrm{j}} \cdot K_{\mathrm{j}}^{\mathrm{m}} \cdot\left(\rho^{\circ \mathrm{x}} / \rho^{\mathrm{M}}\right) \cdot \exp \left\{(l+t) \Lambda_{\mathrm{j}}\right\} \\
& =\sum_{\mathrm{i}} I_{\mathrm{i}}^{\mathrm{ox}} \cdot K_{\mathrm{i}}^{\mathrm{ox}} \cdot \exp \left(l / \Lambda_{\mathrm{i}}\right) /\left\{1-\exp \left(-t / \Lambda_{1}\right)\right\} \\
& I_{\mathrm{C}}^{\mathrm{con}} \cdot K_{\mathrm{C}} \cdot \rho^{\text {ox }} / \rho^{\mathrm{con}} c_{\mathrm{C}}^{\mathrm{con}}\left\{1-\exp \left(-l / \Lambda_{\mathrm{C}}\right)\right\} \\
& =\sum_{\mathrm{i}} I_{\mathrm{i}}^{\mathrm{ox}} \cdot K_{\mathrm{i}}^{\mathrm{ox}} \cdot \exp \left(l / \Lambda_{\mathrm{i}}\right) /\left\{-\exp \left(-t / \Lambda_{\mathrm{i}}\right)\right\}
\end{aligned}
$$

が得られる.ここで $K_{\mathrm{i}}^{o x}=g_{0} \sigma_{0}^{o x} \Lambda_{0} A_{1} / g_{1} \sigma_{\mathrm{i}}^{0 \times} \Lambda_{1} A_{0}$ であ る. $g_{1}$ は一般に光電子の運動エネルギーの関数であつ て, AEI-ES 200 はレターディング比一定で作動してい るので $g_{i}$ は光電子の運動エネルギーに比例している.

$\Lambda_{\mathrm{i}}$ も一般には光電子の運動エネルギーの関数であつ

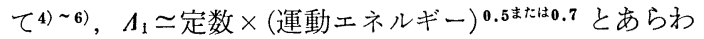
される. 炭化水素污染物質が, 分光器内に存在する払散

\begin{tabular}{|c|c|c|c|}
\hline $\begin{array}{c}\text { Element } \\
\mathrm{A}\end{array}$ & $\begin{array}{c}\text { Electron level } \\
\mathrm{q}\end{array}$ & $\sigma_{\mathrm{Aq}} / \sigma_{\mathrm{O} 1 \mathrm{~s}}$ & Reference \\
\hline $\mathrm{Fe}^{o x}$ & $2 \mathrm{p}_{3 / 2}$ & 1.45 & 2 \\
\hline $\mathrm{Fe}^{\mathrm{m}}$ & $2 \mathrm{p}_{3 / 2}$ & 2.46 & 7 \\
\hline Crox & $2 \mathrm{p}_{3 / 2}$ & 1.71 & 2 \\
\hline $\mathrm{Cr}^{\mathrm{m}}$ & $2 \mathrm{p}_{3 / 2}$ & 1.71 & 2 \\
\hline $\mathrm{Ni}^{0 \mathrm{x}}$ & $2 \mathrm{p}_{3 / 2}$ & 1.53 & 8 \\
\hline $\mathrm{Ni}^{\mathrm{m}}$ & $2 \mathrm{p}_{3 / 2}$ & 7.47 & 7 \\
\hline $\mathrm{Coox}^{\circ}$ & $2 \mathrm{p}_{3 / 2}$ & 3.92 & 7 \\
\hline $\mathrm{Co}^{\mathrm{m}}$ & $2 \mathrm{p}_{3 / 2}$ & 4.53 & 7 \\
\hline Moox & $3 \mathrm{~d}_{5 / 2}+3 \mathrm{~d}_{3 / 2}$ & 3.46 & 9 \\
\hline $\mathrm{Mo}^{\mathrm{m}}$ & $3 \mathrm{~d}_{5 / 2}+3 \mathrm{~d}_{3 / 2}$ & 3.46 & 9 \\
\hline Woox & $4 f_{7 / 2}+4 f_{5 / 2}$ & 2.97 & 10 \\
\hline $\mathrm{Wo}^{\mathrm{m}}$ & $4 f_{7 / 2}+4 f_{5 / 2}$ & 2.97 & 10 \\
\hline Pox & $2 p$ & 0.786 & 8 \\
\hline $\mathrm{Pm}$ & $2 p$ & 0.786 & 8 \\
\hline Box $^{\circ}$ & $1 \mathrm{~s}$ & 0.231 & 11 \\
\hline $\mathrm{B}^{\mathrm{m}}$ & $1 \mathrm{~s}$ & 0.231 & 11 \\
\hline $\mathrm{Si}^{\mathrm{ox}}$ & $2 p$ & $0.303_{5}$ & 11 \\
\hline $\mathrm{Si}^{\mathrm{m}}$ & $2 p$ & $0.303_{5}$ & 11 \\
\hline Sox & $2 p$ & 0.515 & 9 \\
\hline $\mathrm{Cl}$ & $2 p$ & 1.017 & 12 \\
\hline $\mathrm{F}$ & is & 2.054 & 13 \\
\hline
\end{tabular}
ポンプ油に由来するものであれば, $c_{\mathrm{C}}^{\mathrm{con}}$ および $\rho^{\mathrm{con}}$ 推定可能である. また $\sigma_{\mathrm{i}}^{o x} / \sigma_{0}$ あるいは $\sigma_{\mathrm{j}}^{\mathrm{m}} / \sigma_{0}$ が Table 7.1 に示すように, 積分強度の求め方に応じて合理 的に推定されている場合， $\rho^{\mathrm{m}}$ と $\rho^{\mathrm{ox}}$ 安合理的に推定 することができれば式(7)出よび ( 8)で未知数は $l$ と $t$ のみである.そこで式(4)と $\sum_{i} c_{i}^{0 x}=1$ から $c_{i}^{0 x}$ が求ま る.

$$
c_{\mathrm{i}}^{\mathrm{ox}}=\frac{I_{\mathrm{i}}^{\mathrm{ox}} \cdot K_{\mathrm{i}}^{\mathrm{ox}} \cdot \exp \left(l / \Lambda_{\mathrm{i}}\right) /\left\{\left(1-\exp \left(-t / \Lambda_{\mathrm{i}}\right)\right\}\right.}{\sum_{\mathrm{i}}\left(I_{\mathrm{i}}^{\mathrm{ox}} \cdot K_{\mathrm{i}}^{\mathrm{ox}} \cdot \exp \left(l / \Lambda_{\mathrm{i}}\right) /\left\{1-\exp \left(-t / \Lambda_{1}\right)\right\}\right.}
$$

また式 $(5)$ と $\sum_{\mathrm{j}} c_{\mathrm{j}}^{\mathrm{m}}=1$ から $c_{\mathrm{j}}^{\mathrm{m}}$ が求まる。

$$
c_{\mathrm{j}}^{\mathrm{m}}=\frac{I_{\mathrm{j}}^{\mathrm{m}} \cdot K_{\mathrm{j}}^{\mathrm{m}} \cdot \exp \left\{(t+l) / \Lambda_{\mathrm{j}}\right\}}{\sum_{\mathrm{i}} I_{\mathrm{j}}^{\mathrm{m}} \cdot K_{\mathrm{j}}^{\mathrm{m}} \cdot \exp \left\{(t+l) / \Lambda_{\mathrm{j}}\right\}}
$$

Table 7.1. Photo ionization cross-sections relative to that of the Ols electrons. 
表面皮膜が厚く $\left(t \gg \Lambda_{1}\right)$ 下地合金からの 金属状態の スペクトルが事実上観測されない $\left(I_{\mathrm{j}}^{\mathrm{m}}=0\right)$ ときにはも つと単純になり

$$
\begin{aligned}
& I_{\mathrm{C}}^{\mathrm{con}} \cdot K_{\mathrm{C}} \rho^{\text {ox }} / \rho^{\mathrm{con}} \cdot c_{\mathrm{C}}^{\mathrm{con}}\left\{1-\exp \left(-l / \Lambda_{\mathrm{C}}\right)\right\} \\
& =\sum_{\mathrm{i}} I_{\mathrm{i}}^{\mathrm{ox}} \cdot K_{\mathrm{i}}^{\mathrm{ox}} \cdot \exp \left(l / \Lambda_{\mathrm{i}}\right) \cdots \cdots \cdots \cdots \cdots \cdots \cdots \cdots \cdots \cdots \cdots \cdots \cdots \cdots \cdots \cdots \cdots \cdots \cdots \cdots \cdots \\
& c_{\mathrm{i}}^{\text {ox }}=I_{\mathrm{i}}^{\mathrm{ox}} \cdot K_{\mathrm{i}}^{o x} \cdot \exp \left(l / \Lambda_{\mathrm{1}}\right) / \sum_{\mathrm{i}} I_{\mathrm{i}}^{\mathrm{ox}} \cdot K_{\mathrm{i}}^{\circ \mathrm{x}} \cdot \exp \left(l / \Lambda_{\mathrm{i}}\right) \cdots \\
& \text { となる. }
\end{aligned}
$$

したがつて一つの試料から測定されるすべての X線光 電子スペクトルの積分強度を用いることによつて, 下地 合金中の各成分濃度 $c_{\mathrm{j}}^{\mathrm{m}}$, 表面皮膜中の各成分濃度 $c_{\mathrm{i}}^{\mathrm{ox}}$, 表面皮膜の厚さ $t$ 㧊よび炭化水素污染層の厚さ $l$ が一度 に求められる.

このよらな方法をステンレス鋼の表面の解析に適用し た結果は文献 2）3）７）9）12）などに報告されてい る.

\section{文献}

1) K. AsAmı: J. Electron Spectrosc, 9 (1976), p. 469

2) $K$. Asami and $K$. Наshimoto: Corros. Sci., 17 (1977), p. 559

3 ) 浅見勝彦, 橋本功二, 下平三郎: 日本金属学会誌 40 (1976), p. 438

4) J. J. Quin: Phys. Rev., 126 (1962), p. 1453

5 ) $M$. Klasson, $J$. Hedman, $A$. Berndtsson, $R$. Nielsen, $C$. Mordling, and $P$. Melnik: Physica Scripta, 5 (1972), p. 93

6) C. J. Powell: Surface Sci., 44 (1974), p. 29

7 ) $K$. Asami and $K$. Hashimoto: Corros. Sci., 23 (1983)

8 ) $K$. Hashimoto, $K$. Kasaya, $K$. Asami, and $T$. Masumoto：防食技術, 26 (1977), p. 445

9 ) $K$. Teramoto, $K$. Asami, and $K$. Наshimoto: 防食技術， 27 (1978)，p. 57

10) 浅見勝彦，橋本功二: 未発表

11) $K$. Наshimoto, $M$. NaKa, $K$. Asami, and $T$. MASUMOTO：防食技術， 27 (1978), p. 279

12 ) $K$. Hashimoto, $K$. Asami, and $K$. Teramoto: Corros. Sci., 19 (1979), p. 3

13) $K$. Asami and $K$. Наshimoto: Corros. Sci., 19 (1979), p. 1007

\section{AESによる定量分析と状態分析に関 する研究}

東京大学生産技術研究所 本間 禎一

\section{1 はじめに}

オージェ電子分光 (AES) とX 線光電子分光 (XPS) は，いま普及段階にある有力な表面分析法である，とこ ろで C.C. Ghang は薄膜の分析手法として両者を取り 上げて, 現用装置の性能比較を行い, 総合に颃いて XPS が優れているが理論的性能限界を考慮するとき AES に も期待できる潜在能力があることを指摘している1). そ
こでは, 感度, 迅速性, 空間分解能, 深さ方向分解能, 化学結合に関する情報, 試料損傷, 定量分析, および静 電荷効果などが検討されている.

表面分析の普及化と関連する動向として, 分析の標準 化のための調査活動が進められている.ASTM (米国) では表面分析に関する E-42 委員会 (委員長 C.J. PoWELL）が中心となつて AES/ESCA の合同調査活動が 進められ, 共通の試料 (ESCA は $\mathrm{Gu}, \mathrm{Au}, \mathrm{Ni}, \mathrm{AES}$ は $\mathrm{Cu}, \mathrm{Au}$ )を用いて相対強度比および入射電子の運動 エネルギーの測定が行われた. その報告2)によると, 測 定值は異なる装置, 測定者によつてばらつきを示し, 両 方法とも，その範用はオーダーに及んだと述べられてい る. 操作方法, データ解析, 補正方法の標準化が必要で あることが指摘されている.

ここでは, AES について前述の潜在能力を顕在化せ しめるために，実現をはばんでいる問題を明らかにし， 併せて装置の開発を目的として進めている課題の研究に ついて中間的に報告し, 次いで定量電子分光のための標 準の測定操作, データ処理の “処方”を見出す目的で調 査を開始した装置関数制御方式について述べる.

\section{8 .2 AES による定量分析}

$8 \cdot 2 \cdot 1$ 化学効果を考慮した相対感度係数法

AES による定量分析には, 一般に相対感度係数法が 用いられているが, 多くの場合, 化学効果は考慮されて いない. そこで, 化学効果を考慮した相対感度係数法に よる金属-酸化物系の定量分析を対象事例として, 金属 状態と酸化状態のオージェスペクトルを系統的に調查 し，酸化による化学効果を明らかにした. 実用合金元素 として重要な遷移金属（Ti～Zn $)$ とその酸化物につい て, 定量分析に用いられる LMM 系スペクトルの化学 効果を調査した結果，一般的な傾向として，価電子帯に 属する電子が関与するピークは化学効果によつて相対感 度係数が変化することが示された て, 酸化物薄膜中の 深さ方向の定量分析を行(4), ま た化学効果を利用して，界面の同定が行えることを示 した5).さらに, 計算の自動化とプロットアウト化を進 め, 高温酸化の研究に応用した. 寸なわち, ステンレス 鋼の基本系である Fe-18 Cr 合金単結晶を用い, その高 温酸化層の組成, 構造, 結晶学的方位関係に及ぼすェピ タキシ効果の研究6) を行つた.

併せて, 強磁性体の電子分光に抢ける磁気特性の変化 の影響を調査した.

$8 \cdot 2 \cdot 2$ スペクトル合成法（線形結合法）

装置特性を考慮して信頼できるスペクトルを求めるこ とによつて，金属-酸化物系のように化学状態の異なる 複合系についても定量分析が可能であることを示した7).

さらに，各成分スペクトルが線形独立であれば，各成 分の寄与を求め, 重なり效果を補正して，より精度高く 
定量分析ができることを示した8) 10)．原子番号効果， 選択スパッタ効果が小さいことが期待できるモデル系と して, Ni-Co 2 元合金について,それぞれの成分元素の 基準スペクトルから線形結合による合成スペクトルを求 め，実測スペクトルとの照合によつて，25.2 at\%（化学 分析值 23.8 at \% ) 拉よび 49.8 at\%（同 50.5 at\%) の 結果をえた. 理論的予測では表面の組成変化は少なく， 予測とほぼ一致する結果が得られたことから，この系は 表面分析の標準試料となることが期待される.

スペクトル合成による多元系の定量分析に関連して, 異なる状態を含む複合系の定量状態分析の具体例として $\mathrm{Si}-\mathrm{SiO}_{2}, \mathrm{Ni}-\mathrm{NiO}$, 炭化物-グラファイト (Nb 基) の 各系が調査された。

AES がもつている感度, 迅速性, 空間分解能を損な らことなく定量分析の精度を高められる電子分光器の開 発 ${ }^{11)}$ を進めている. 測定用と解析用の 2 台のマイクロコ ンピュータを用いることにより実験室規模で $\mathrm{S} / \mathrm{N}$ 改善 処理と合わせて測定時間の短縮が進められた. その結 果, (1) 深さ方向の分析における微量成分の分析感度之 精度が向上し，(2) 適当なモ二ターと転送を行うことに よつて同時的にデータの解析が可能となり，(3)スペク トルの微細構造の判別, 解析が容易となるなどの見通し がえられた。

\subsection{AES による状態分析}

遷移時間不確定性のために，オージェピークが数 $\mathrm{eV}$ の幅をもつことから AES は状態分析法として不利であ るとされている. しかし，十分に大きな信号量が検出で きれば，原理的には，代表值を確定できる．実際に，市 販の装置（エネルギー分解能 $\Delta E / E \sim 0.6 \%$ ）を用いた 装置特性についての調査結果から，相互作用の小さいス ペクトル系を標準として選び, 装置関数に依存しないで 測定できる量を求め, スペクトルの数学的処理によつて 各成分スペクトルを解析して，高いエネルギー領域（た とえば>500 eV) であつても状態変化を捕えられること を示した12).

その際, $\pm 10 \%$ の定量精度を得るためには, 装置の安 定性を $\pm 1 \%$ 程度にする必要があることを明らかにし た。

\section{4 装置関数制御による電子分光}

AES による定量分析の検出感度, 精度, 再現性, 定 量性を高め, 併せて高速化を実現するために装置関数の 制御によつて最適条件で電子分光を行う方式の開発のた めの調査研究を行つた. すなわち, (1)市販の分光器 (CMA) について装置特性の調査を行い, CMA 操作お よび動作の最適条件を解析した. 次いで電子分光器の分 解能を改善するため, 「阻止電位式一段型円筒鏡分光器」 の開発に着手し，（2)装置関数制御を行らためにコンピ
ュータによる制御システムの開発を進めた.

また, 定量分析, 状態分析の標準化とも関連して, 標 準スペクトルの収集を開始した.

スペクトル合成の手法を利用して, 装置関数を用いる スペクトルの变換についても開発化を進めた。 これは,

異なる装置, 測定条件でえられるスペクトルの相互比較 および変換と関連して括り，標準スペクトルの収集とも 関係するものである.

スペクトルのデータ処理化によつて可能となつた微量 成分の検出感度の向上およびスペクトルの微細構造の判 別, 解析が可能となつた実例として，アルミニウムの陽 極酸化皮膜中の B，Pなどの微量元素の分布と状態の測 定, 評価が挙げられる ${ }^{13)}$. 別の例として, イオン照射に よつて注入された微量の Arのスペクトルがマトリック スの種類によつて形状が変化することが観察された. こ の変化は原子間遷移によるものと考えられる.

AES による定量分析に関する研究とは別に, 鋼材表 面の評価に関して次の調査, 研究も行われた.

(1) ステンレス鋼 $(304,430, F e-18$ Cr) 表面の酸 化挙動

（2）鋼材 (430) 表面の偏析挙動とその酸化, 気体吸 着への影響14)

これらは, 前述の強磁性体の電子分光に括ける磁気特 性の変化の影響とも関連して, 磁気の影響を除去または 制御できる分光システムの開発による表面評価法の確立 とつながつている.

\section{交献}

1) C. C. Chang: J. Vac. Sci. Technol., 18 (1981), p. 276

2 ) G.J. Powell, $N . E$. Erickson, and T.E. MAdey: J. Electron Spectroscopy Rel. Phenomena, 17 (1979), p. 361; 同上, 25 (1982), p. 87

3 ) 石黒勝彦, 本間襀一: 日本金属学会誌, 45 (1981), p. 360

4) $K$. Ishiguro and T. Homma: J. Electrochem. Soc., 127 (1980), p. 1205

5 ) $K$. Ishiguro and T. Homma: Proc. of Intern. Conf. of High Temperature Corrosion, NACE (1982)

6 ）大島一英, 本間禎一, 田中彰博：日本金属学会秋 期大会 (1982. 9) 講演概要, p. 367

7 ) 田中彰博, 本間禎一: 生産研究, 32 (1980), p. 476

本間禎一, 田中彰博, 石黑勝彦：マイクロビーム アナリシス第 141 委員会第 28 回研究会資料 (1981. 5), p. 21

8 ) 田中彰博, 本間禎一：応用物理学連合講演会予稿 (1981. 3), p. 375

9) A. TAnaka and T. Номma: Abst. of 9th Intern. Conf. on Atomic Spectroscopy and XXII Colloq. Spectroscopicum Intern. (1981 -9), p. 249

10)田中彰博, 本間禎一: 応用物理学会講演予稿 (1981. 10)，p. 273，401

11）国有特許（国内）出願（発明者：田中彰博，本間 
禎一）公示中

12) 田中彰博, 本間禎一：日本金属学会春期大会予稿 (1982. 4), p. 191

13）望月 隆, 田中彰博, 本間禎一, 増子 昇: 未発 表

14) 竹森 信, 本間禎一, 石黒勝彦: 日本金属学会秋 期大会 (1982. 9) 講演概要， p. 345

\section{9. 鉄鋼表面酸化皮膜の深さ方向の組成 分布の定量}

\author{
北海道大学工学部 \\ 瀬尾 畺浩 佐藤 教男
}

鉄鋼表面に形成される非常に薄い酸化皮膜（1～100 $\mathrm{nm})$ の深さ方向の組成分析には,スパッタ・エッチング 法を組み合わせたオージェ電子分光法 (AES) が用いら れている.スパッタ・エッチング法とは，アルゴンなど の不活性ガスイオンビームを固体表面に入射させ，入射 イオンの運動エネルギーの一部を貪つた表面原子が最終 的に固体表面から放出される現象を利用した表面剝離法 である.この手法を用いて表面酸化皮膜の深さ方向の組 成分布を正確に求めるためには, AES による皮膜組成 定量の問題（相対感度, 脱出深さ, 背面散乱因子など） のほかに皮膜のスパッタ・エッチングに付随する諸問題 (スパッタリング収率, 優先スパッタリング, ノックオン 効果など）を解決しなければならない。

深さ方向の定量には，まず皮膜および下地金属のスパ ッタリング速度を知る必要がある. 皮膜のスパッタリン グ速度は下地金属のスパッタリング速度と異なり，その 大小関係は皮膜打よび下地金属の種類に依存する．KELLY $\left.{ }^{1}\right)$ らは特定のスパッタリング条件 $(10 \mathrm{kV}, \mathrm{Kr})$ のも とで，金属と金属酸化皮膜のスパッタリング収率の比較 を抗こなつている．スパッタリング速度 $v(\mathrm{~nm} / \mathrm{s})$ とス パッタリング収率 $Y$ (atoms/ion) との間には次式の関 係が成立する。

$$
v=\frac{M \cdot Y \cdot j_{\mathrm{p}}}{\rho \cdot F}
$$

ここで，Mは試料原子の質量 $(\mathrm{g}), \rho$ は試料の密度 $(\mathrm{g}$. $\left.\mathrm{cm}^{-3}\right), j_{\mathrm{p}}$ は入射イオンビームの電流密度 $\left(\mu \mathrm{A} \cdot \mathrm{cm}^{-2}\right)$, $F$ は Faraday 定数である。ただし，試料が酸化皮膜の 場合， $M$ および $\rho$ の值に皮膜の平均原子質量および平 均原子密度を用いる必要がある。スパッタリング収率に 関して衝突カスケード機構と熱スパイク機構がある．無 定形の単原子固体のスパッタリングに関する SIGMUND の衝突カスケード理論2)によれば，スパッタリング収率 $Y\left(E_{\mathrm{k}}, \theta\right)$ は次式で与えられる.

$$
Y\left(E_{\mathrm{k}} \cdot \theta\right)=\frac{0.042 \cdot \alpha\left(M_{2} / M_{1}, \theta\right) \cdot S_{\mathrm{n}}\left(E_{\mathrm{k}}\right)}{U_{\mathrm{b}}}
$$

ここで， $\alpha$ は入射イオンの質量 $M_{1}$ と固体表面原子の質
量 $M_{2}$ の比抢よび 入射角 $\theta$ (試料に垂直方向を $\theta=0^{\circ}$ にとる)で決まる定数, $S_{\mathrm{n}}\left(E_{\mathrm{k}}\right)$ は弾性散乱断面積 $\left(A^{\circ} \mathbf{2}\right)$, $E_{\mathrm{k}}$ および $U_{\mathrm{b}}$ は，入射イオンの運動エネルギー $(\mathrm{eV})$ および原子の表面結合ェネルギー $(\mathrm{eV})$ である、スパッ タリング収率の入射角依存性は， $\theta=0^{\circ}$ に蛙けるスパッ タリング収率 $Y(0)$ を基準にとると, $Y(\theta)=Y(0)(\cos$ $\theta)-f$ で与えられる。 $f$ は $M_{1} / M_{2}$ に依存する変数であ り，ほぼ 1 に近い值をとる．純金属のスパッタリング収 率に関して実測值とSIGMUND の理論値2) との間に比較 的良い一致がみられる。衝突カスケード機構では，試料 原子の一部が格子点から吒き出されるか，他の試料原子 は格子点にあり，もとの骨格を保持しているのに対し， 熱スパイク機構では，イオン照射を受けた部分の骨格は むはや存在せず，試料原子が局部的にガスに近い状態に あると考えられる．熱スパイク機構によるスパッタリン グは表面結合ェネルギーの小さい重金属試料を重元素イ オンで照射した時に起こりやすく，この場合，スパッタ リング収率は衝突カスケード機構から予想されるよりも 大きくなる．金属酸化物のスパッタリング収率1)につ いても衝突カスケード機構で説明されるもの $\left(\mathrm{Al}_{2} \mathrm{O}_{3}\right.$, $\mathrm{MgO}, \mathrm{Ta}_{2} \mathrm{O}_{5}$ など） と熱スパイク機構を考慮しなけれ ばならないもの $\left(\mathrm{WO}_{3}, \mathrm{~V}_{2} \mathrm{O}_{5}, \mathrm{MoO}_{3}\right.$ など）とがある。

ところで鉄鋼材料の主成分である鉄, ニッケルおよび クロムの表面酸化皮膜のスパッタリング速度（あるいは スパッタリング収率) および皮膜と下地金属とのスパッ タリング速度の大小関係を調べた研究は少ない, McINTYRE ${ }^{3)}$ らは, $\mathrm{Fe}_{3} \mathrm{O}_{4}, \mathrm{NiO}$ および $\mathrm{Cr}_{2} \mathrm{O}_{3}$ 皮膜のスパッ タリング速度を特定のスパッタリング条件 $\left(3 \mathrm{kV}, \mathrm{Ar}^{+}\right)$ で比較し， $\mathrm{Cr}_{2} \mathrm{O}_{3}$ 皮膜のスパッタリング速度 $(1.4 \mathrm{~nm}$. $\left.\min ^{-1}\right)$ が $\mathrm{Fe}_{3} \mathrm{O}_{4}$ および $\mathrm{NiO}$ 皮膜のスパッタリング速 度（ともに $4.0 \mathrm{~nm} \cdot \mathrm{min}^{-1}$ ) に比べて極端に低いことを 報告している。また， $\mathrm{Cr}_{2} \mathrm{O}_{3} / \mathrm{Cr}$ 系4)执よび $\mathrm{Fe}_{2} \mathrm{O}_{3} / \mathrm{Fe}$ $\mathrm{Ni}$ 合金系5) では, いずれる下地のスパッタリング速度 が皮膜のスパッタリング速度に比べて大きくなる．スパ ッタリング速度およびスパッタリング収率の測定には, マイクロバランス, 表面あらさ計特よび光干渉計が用い られている．しかし，皮膜の場合，エリプソメーター5)6) を用いると皮膜厚を正確に測定できるので，他の方法に 比べて測定精度は高い，最近では，二光束レーザ干渉 計7) およびレーザ励起蛍光スペクトル法8）により，その 場でスパッタリング速度を連続して測定する方法が開発 されている．深さ方向のカチオン分率が異なる合金表面 酸化皮膜では，スパッタリング速度が深さ方向で異なる ことが予想され，深さ方向のスパッタリング速度の連続 測定が必要となる.

スパッタリング過程は本来統計的な性質を有し，スパ ッタリングが進行するにつれて表面粗度が増加し，深さ 方向の測定精度を低下させる. 仮に, 厚さ $Z$ の酸化皮 膜の深さ方向の酸素濃度分布がステップ関数であらわさ 
れ，スパッタリング過程によつて生じた皮膜/下地界面 の濃度分布のひろがりを $\Delta Z$ とする. HofMANN9) は最 表面に露出した原子が同じ確率でスパッタリングされる 理想的スパッタリングモデル10)を用いて，皮膜/下地界 面の濃度分布が, Gauss の積分分布関数であらわされる ことを示した．深さ方向の測定精度を $\Delta Z / Z$ であらわ すとすれば次式が得られる。

$$
\Delta Z / Z=2(a / Z)^{1 / 2}
$$

ここで, $a$ は皮膜の単原子層の厚さに相当する定数であ る.下地金属の上に異種金属を蒸着した系 $(\mathrm{Cu} / \mathrm{Ni}, \mathrm{Au}$ $/ \mathrm{Ni}$ など）拈よび $\mathrm{Nb}_{2} \mathrm{O}_{5} / \mathrm{Nb}$ 系などの界面に括ける 酸素濃度分布のひろがり ${ }^{11}$ は Fig. 9.1 に示されるよう に(3)式に良く一致し，a値として単原子層に相当す る厚さ $(0.3 \mathrm{~nm})$ が得られている. しかし皮膜/下地界 面に打ける酸素濃度分布は, $\mathrm{Nb}_{2} \mathrm{O}_{5} / \mathrm{Nb}$ などの例外を除

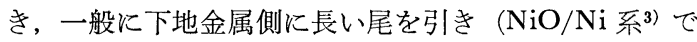
は特に顕著である), Gauss の積分分布関数からずれを 生ずる. 深さ方向の測定精度を低下させる他の要因とし ては, 優先スパッタリング, ノックオン効果拉よびカス ケード混合による表面変質層の形成があげられる。スパ ッタリングが定常状態に到達すると, 変質層の厚さは一 定となり， $\Delta Z / Z$ は $Z^{-1}$ に比例することになる。SHI$\mathrm{MIZU}^{12}$ は，スパッタリング過程を条件付き確率として取 り扱われる Stochastic Process とみなし， $\Delta Z / Z$ をあ らわす式として次式を得ている。

$$
\frac{\Delta Z}{Z}=2 \varepsilon(a / Z)^{1 / 2} \sqrt{1+Y}
$$

ここでもはスパッタリング条件（入射イオン種，入射イ オンの運動エネルギー, 試料の物質など）に依存する1 より小さな変数，Yはスパッタリング収率である.

酸化皮膜では通常, 酸素の優先スパッタリングが起 き，スパッタリング条件に依存して低価数の皮膜あるい は金属状態一と皮膜の還元が進行する.酸化物生成の標 準自由エネルギー， $\Delta G_{\mathrm{f}}^{\circ}$ の比較的大きな $\mathrm{Al}_{2} \mathrm{O}_{3}$ 扰よ び $\mathrm{Cr}_{2} \mathrm{O}_{3}$ などの皮膜では, 酸素の優先スパックリングは

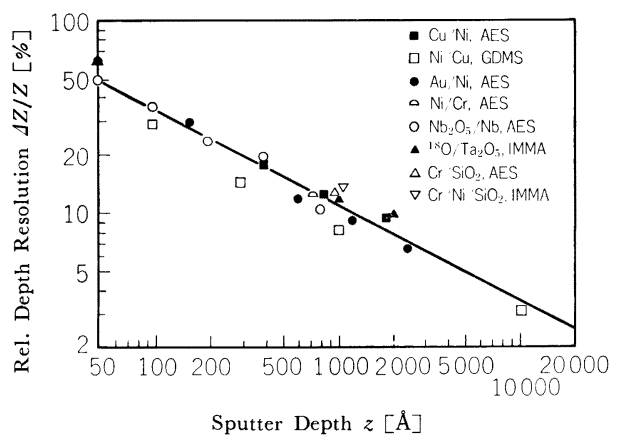

Fig. 9.1. Relation between film thickness $Z$, and relative depth-resolution $\Delta Z / Z$, at the film/substrate interface for various systems. ${ }^{11)}$
起こりにくい，乙かし $\Delta G_{\mathrm{I}}^{\circ}$ の大きな酸化物でも, 低級酸 化物が熱力学的に安定に存在し, 高級酸化物から低級酸 化物への自由エネルギー変化の比較的小さな酸化物（例 えば $\mathrm{Nb}_{2} \mathrm{O}_{5}{ }^{11}$ 13) 抢よび $\mathrm{MoO}_{3}{ }^{1)}$ など) では酸素の優先スパ ッタリングが容易に進行し, 低級酸化物へと変化する. 優先スパッタリング，ノックオン効果掞よびカスケード 混合による表面変質層の推定に種々のモデルが提案され ている. Ishitani と Shimizu14) はモンテカルロ法によ り，ンックオン効果抢よびカスケード混合による表面変 質層の厚さをシミュレーションしている. MICHELLL) は鉄表面酸化皮膜の変質層の組成拉よび厚さを入射イオ ンの種類および入射イオンの運動ェネルギー (1 4 kV) を変えて調べている. 変質層の厚さは入射イオンの運動 エネルギーの増加とともに $1 \mathrm{~nm}$ から $6 \mathrm{~nm}$ 一と増加す るが, アルゴンイオンよりも質量の大きいキセノンイオ ンを用いた方が変質層の厚さは薄くなる。スパッタリン グは表面層に種々の欠陥を導入し，バルクから表面への 原子の拡散過程を促進する. この場合, 表面混合層の内 側に払散層がひろがることになり, 変質層の厚さは増加 する. したがつて表面変質層の推定には拡散促進効果16) を考慮する必要がある. 深さ方向の測定精度を向上させ るには, 表面変質層の厚さを極力, 薄くする必要があ る. そのためには低エネルギー (1 kV 以下) の重元素 イオンを斜めの角度から試料表面に入射させると良い。 以上, 深さ方向の定量に関して, スパッタ・エッチング に付随する諸問題について検討を拈こなつた. AES の 定量性に関する問題については, 紙面の関係上, 省略す るが，深さ方向の測定精度に影響を及注す因子として， オージェ電子の脱出深さがある. 脱出深さを考慮した皮 膜の深さ方向の組成分布の定量で特に問題になるのは脱 出深さのマトリックス依存性 ${ }^{17)}$ である.

今後, 深さ力向の測定精度を低下させる諸因子を考慮 して皮膜の深さ方向の真の組成分布を推定する方法が開 発されることを期待する。なお，スパッタリング過程の 詳細については石谷ら ${ }^{18)}$ 拈よび志水ら ${ }^{19)}$ の総説を参照さ れたい。

\section{交献}

1) R. Kelly and N. Q. LAm: Radiat. Eff., 19 (1973), p. 39

2) P. Sigmund: Phys. Rev., 184 (1969), p. 383

$3)$ N.S. MaIntyre and D. G. Zetaruk: J. Vac. Sci. Technol., 14 (1977), p. 181

$4)$ R. N. YASKo and L. J. Fried: Rev. Sci. Instr., 43 (1972), p. 335

5 ) 瀬尾真浩, 佐藤教男: 表面科学 3 (1982), p. 11

6) R. G. Hart and G. W. Simmons: J. Vac. Sci. Technol., 15 (1978), p. 714

7 ) $J$. Kempr: Sims II, ed. by $A$. Benninghoven, $C$. $A$. Evans, $R$. $A$. Powell, $R$. Shimizu, and $H$. $A$. Storms, (1979), p. 97 [Springer, Berlin]

8 ) $R$. Behrisch, $J$. Roth, $J$. Bohdansky, $A . P$. Martinelli, $B$. SchweEr, $D$. Rusbuldt, and $E$. 
Hintz: J. Nucl. Mater., 93/94 (1980), p. 645

9 ) S. Hofmann: Appl. Phys., 9 (1976), p. 59; Surf. Interface Anal., 2 (1980), p. 148

10) A. Benninghoven: Z. Phys., 230 (1970), p. 403

11) S. Hofmann: Appl. Phys., 13 (1977), p. 205

12) R. Shimizu: Appl. Phys., 18 (1979), p. 425

13) P. C. Karulkar: J. Vac. Sci. Technol., 18 (1981), p. 169

14) T. Ishitani and R. Shimizu: Appl. Phys., 6 (1975), p. 241

15) D. F. Michell, G. I. Sproule, and $M . J$. Graham: J. Vac. Sci. Technol., 18 (1981), p. 690

16) P. S. Ho: Surf. Sci., 72 (1978), p. 253

17) $M . P$. SeAh and $W . A$. Dench: Surf. Interface Anal., 1 (1979), p. 2

18）石谷 亭，田村一二三：表面，18 (1980), p. 38

19）志水隆一, 山村泰道, 松波紀明, 森田健治, 西堂 雅博，伊藤憲昭：応用物理, 50 (1981), p. 470

\section{0. 低速イオンによる合金の表面損傷}

電子技術総合研究所 清水 肇 村上 寛

\section{$10 \cdot 1$ 序}

合金材料のスパッタリング現象の解明は核融合炉壁材 料の開発に関し重要な課題となつている. 一つの問題点 は，スパッタリングによる壁材料の損耗効果であり，他 の 1 点は, 放電中に鉄などの Z 番号の大きい原子がプラ ズマに飛び込むと輻射によりプラズマの温度が上昇しな い効果である，その他に，入射イオンが壁内部に侵入す ることで形成される種々の格子久陥に寄因する照射誘起 抎散が，壁温度が $600 \sim 700^{\circ} \mathrm{C}$ 程度に上がると合金では 重要になつてくる.

耐イオン衝撃性に優れた合金材料を開発する上で, $\mathrm{Cu}-\mathrm{Ni}$ 合金をモデル系に取り上げ1), 低速希ガスイオン による表面ならびに表面近傍の組成変化やガス吸着特性 の解析を行うとともに、レーザ蛍光法による放出物質の 組成, 速度分布などを明らかにする必要がある。

\section{2 オージェ電子分光法, X線マイクロアナリ シス法による表面・表面近傍の組成解析}

$\mathrm{Cu}-\mathrm{Ni}$ 合金を室温で $\mathrm{Ar} イ$ イ $(3 \mathrm{keV})$ 衝撃する と, 表面でニッケル富化が AES で検出される. この現 象は銅のスパッタ率の方がニッケルより大きいことに寄 因する “選択スパッタリング” と解釈され, 表面分析の 分野では重要な現象として, 10 年以上前から種々の合 金系で基礎研究が進められている.

イオン衝撃を受けた試料を真空中で焼鈍（150～600

C) すると, 銅の表面偏析が特こり, 高い温度では母相

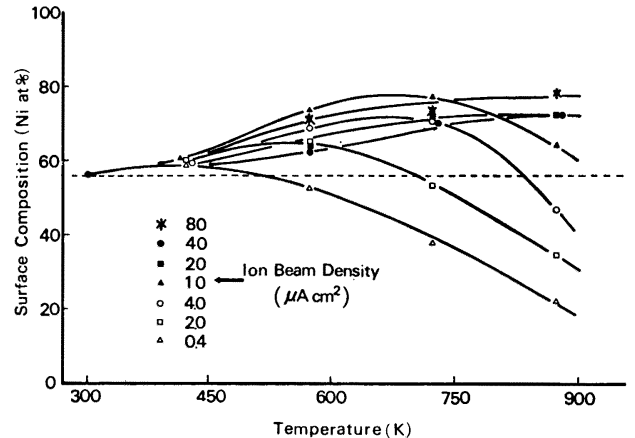

Fig. 10.1. Surface composition changes of a 40 at $\% \mathrm{Ni}$ alloy, having average grain diameter 1-3 $\mathrm{mm}$, after sputtering of a $3 \mathrm{keV}$ argon ion beam at various temperatures and ion beam densities for $1 \mathrm{~h}$. The dotted line indicates the eqilibrium composition expected after sputtering at room temperature.

濃度を上まわる値を示す。すた偏析速度も著しく速く， $600^{\circ} \mathrm{C}$ では数秒のオーダである.これは, 表面ェネルギ 一を極小に保つ熱力学的な効果と, 照射により形成され た格子欠陥が払散を促進しただと解釈できる. 表面近 傍でイオンによる銅の優先的虽離と偏析現象といら逆向 きの作用が起こるため, 高温でのスパッタリングが合金 の場合単純でないことがわかる.

Fig. $10 \cdot 1$ は $40 \mathrm{at} \% \mathrm{Ni}-\mathrm{Cu}$ 合金を $150 \sim 600^{\circ} \mathrm{C}$ の範 曲でイオン密度を変えながらイオン衝撃を行つたときの 表面組成変化を AES で測定した結果である. 低イオン 密度†では, 豩離速度より銅の偏析速度が大きいため に，温度が高くなるにつれて表面は銅濃度が高くなる。 イオン密度が大きくなるにつれ, 銅の濃度が減少し始め, $600^{\circ} \mathrm{C}$ の場合, $40 \mu \mathrm{A} / \mathrm{cm}^{2}$ では $80 \mathrm{at} \% \mathrm{Ni}$ 相当までニッ ケルの富化が起こる.

このような組成変化は EPMA でも検出され, EPMA の分析深さを考慮するとかなり深い領域まで及んでいる ことがわかる. 損傷層内での組成の変化を求める目的で 試料をイオン衝撃法により徐々に剥離すると, $40 \mu \mathrm{A} /$ $\mathrm{cm}^{2}$ の入射イオンで $300,450,600^{\circ} \mathrm{C}$ の各温度で衝 撃 した試料中の銅の欠乏層の深さは，それぞれ 150，420， $680 \AA$ 程度であつた. 温度が高まるにつれ拡散が促進さ れてゆくことがわかる.

この久乏層の形成は, 表面からの銅の優先的な剥離之 内部からの銅の供給の平衡条件によつて起こるもので,

Fick の第 2 法則に剥離条件を加えて解析すると, 損傷 層内での拡散定数を求めることができる.Fig. 10.2 に は, このようにして求めた照射誘起払散定数 $\left(D^{*}\right)$ と正 常な体拡散定数 $(D)$ とを比較して示した. 筆者ら以外 のデータとの間には多少のばらつきも認められるが，注 目すべき点は活性化エネルギーを示す傾斜が著しく異な

$\dagger 4 \mu \mathrm{A} / \mathrm{cm}^{2}$ のイオン密度で一原子渞㓦晟するの計算上 $23 \mathrm{~s}$ 要する. 


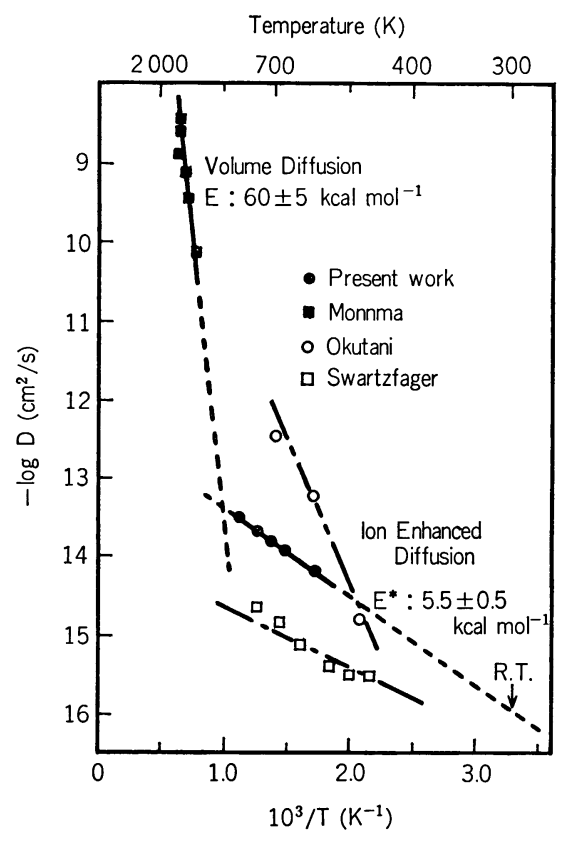

Fig. 10.2. The effect of sputtering temperature on the ion-enhanced diffusion of copper alloy having average grain diameter $1-3 \mathrm{~mm}$ and the apparent activation energy. The results of Okutani6) were obtained by AES and those of Swartzfager ${ }^{7)}$ were obtained by ISS. The normal lattice diffusion coefficients were obtained by radiographic result of Monnma ${ }^{2}$.

つていることである. 門間2)らによれば，正常な体拡散 の活性化ェネルギーは $60 \mathrm{kcal} / \mathrm{mol}$ であるのに対し, 照射誘起払散では僅か $5 \sim 6 \mathrm{kcal} / \mathrm{mol}$ となつている. この值は㧪散機構が損傷層内では全く異なつていること を示し，透過電顕による格子像を利用した損傷層の金属 組織の観察が有効であることがわかる.

\section{3 レーザ共鳴散乱とスパッタリング}

イオン衝撃によつて固体表面から放出された粒子の中 にはかなりの量の中性原子が含まれていて，これらを高 感度で分析する新しい手法が実用化されつつある. 手法 の原理はいわゆる蛍光分析であつて，かなり古くから鉄 鋼材料の分析には用いられているものであるが, 最近に なつて波長可変レーザが利用できるようになり，各方面 でレーザ共鳴散乱法が利用されるようになつてきだ)。

レーザ共鳴散乱法で検出可能な原子の個数は，打打よ そ $10^{5} \sim 10^{8}$ atoms $/ \mathrm{cm}^{3}$ と言われているが，チャンピオ ンデータとしては数個の $\mathrm{Na}$ 原子を検出したとの報告も ある.

レーザ共鳴散乱法を実用化していく上で一番の問題点 は，中性原子をいかに多く励起し，かつ効率良く蛍光を

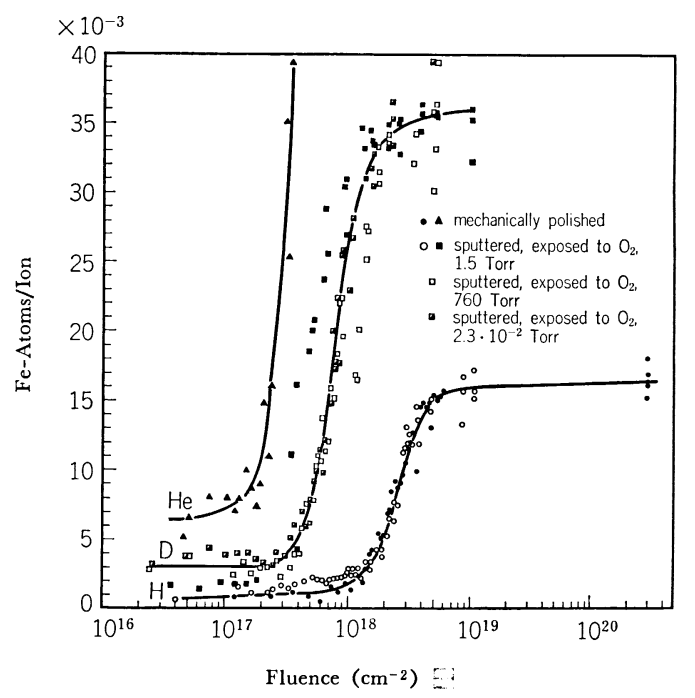

Fig. 10.3. Effect of oxygen adsorption of the sputtering yield of iron measured by means of laser fluorescence method by Behrisch et al.

検出する光学系を開発するかにかかつている. 励起に必 要な光は紫外領域で, YAG レーザの高調波やエキシマ レーザの利用が考学られるが，共鳴吸収波長と一致した 場合以外には使光ないので, 一般には色素レーザと非線 形結晶を用いて必要な波長を得ている。筆者はフラッシ ュランプ励起の色素レーザを用いた装置の開発を試みて いる.

レーザ共鳴散乱法の高感度性を示す例として，MaxPlanck 研究所の BEHRISGH ${ }^{4}$ らによつて報告された鉄 のスパッタリング収率に及ぼす単原子層程度の吸着酸素 ガスの効果を Fig. 10.3 に紹介する. エメリ紙によつ て研磨を行つた鉄多結晶試料を $6 \mathrm{keV}$ の $\mathrm{He}^{+}$と $2 \mathrm{keV}$ の $\mathrm{H}^{+}, \mathrm{D}+$ で衝撃した場合に，それぞれのイオンを $2 \times$ $10^{17}, 1 \times 10^{18}, 2 \times 10^{17}$ 個 $/ \mathrm{cm}^{2}$ 打ち込むと急激に鉄のス パッタリング収率が大きくなる. 同様の現象は一度清浄 化処理を行つた試料に再度酸素ガスを吸着させた場合で も認められる. 入射イオンの総数は, ほぼ酸素吸着層を 一原子層剝離する量汶対応している。単原子量の酸素の 存在によつてスパッタリング収率が著しく低くなること は, 核融合炬内で起こる損傷の度合を弱めている可能性 があり，今後の検討が必要である.

低速イオンによるスパッタリングの実験を共鳴散乱法 を用いて行う問題点は, 先に述べた残留ガスの影響があ るため,イオン銃を差動排気する必要があることや, 絶 対量を光学的に決めることが難しいために, 相対変化に 限られることである. 定量解析を行らためには, 現在の ところマイクロバランスの併用が最も簡単な手法である が, 既知濃度の希薄液体試料の利用も有効であろう. 


\section{$10 \cdot 4$ おわりに}

単位金属のスパッタリングに関しては，測定データの 充実徐々にはかられる一方, スパッタリング収率や放 出物質の角度分布などのシミュレーションもかなり良く 実験と合うようになり, 固体とイオンの相互作用の解明 が進んでいる5). しかし, 化合物や合金, あるいは高温 下でのこれらのスパッタリングに関してほとんど解明さ れてないのが現状であつて, 耐イオン衝撃材料の開発を 進めてゆく上で研究が大いに必要とされる.

$$
\text { 交献 }
$$

1) 清水 肇, 古山直行, 石田 洋一: 日本金属学会 誌, 45 (1981), p. 768

$H$. Shimizu, $M$. Ono, $N$. Koyama, and Y. IshiDA: J. Appl. Phys., 53 (1982), p. 3044
清水 第：真空, 25 (1982), p. 111

2) 門間改三，須藤一，及川洪：日本金属学会誌 28 (1964), p. 192

3 ) 前田三男，村岡克紀，浜本 誠，赤崎正則，宮副 泰：レーザ研究, 9 (1981)， p. 237

4 ) $R$. Behrisch, $J$. Roth, $J$. Bohdansky, $A$. $P$. Martienelli, $B$. Schweer, $D$. Rusbüldt, and E. Hintz: J. Nucl. Mat., 93 \& 94 (1980), p. 645

5 ) 志水隆一, 山村泰道, 松波紀明, 森田健治, 西堂 雅樹, 伊藤憲昭：応用物理, 50 (1981), p. 420 山村泰道, 志水隆一, 清水 肇, 伊藤憲昭：真空 26 (1983), p. 69

6) $T$. Okutani, $M$. Shikata, and $R$. Shimizu: Surface Sci., 99 (1980), L 410

7 ) $D . G$. Swartzfager, S. B. Ziemegki, and $M$. J. Kelley: J. Vacuum Sci. Technol., 19 (1981), p. 185 